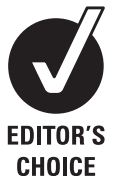

CHOICE

\title{
Effect of late preterm birth on longitudinal lung spirometry in school age children and adolescents
}

\author{
Sarah J Kotecha, ${ }^{1}$ W John Watkins, ${ }^{2}$ Shantini Paranjothy, ${ }^{2}$ Frank D Dunstan, ${ }^{2}$ \\ A John Henderson, ${ }^{3}$ Sailesh Kotecha ${ }^{1}$
}

\begin{abstract}
- Additional materials are published online only. To view these files please visit the journal online (http://thorax.bmj. com/content/67/1.toc).

${ }^{1}$ Department of Child Health, School of Medicine, Cardiff University, Cardiff, UK ${ }^{2}$ Department of Primary Care and Public Health, School of Medicine, Cardiff University, Cardiff, UK

${ }^{3}$ School of Social and Community Medicine, University of Bristol, Bristol, UK
\end{abstract}

\section{Correspondence to} Professor Sailesh Kotecha, Department of Child Health, School of Medicine, Cardiff University, Heath Park, Cardiff CF14 4XN, UK:

kotechas@cardiff.ac.uk

Received 12 April 2011 Accepted 29 July 2011 Published Online First 27 September 2011

\begin{abstract}
Background Rates of preterm birth have increased in most industrialised countries but data on later lung function of late preterm births are limited. A study was undertaken to compare lung function at $8-9$ and 14-17 years in children born late preterm (33-34 and 35-36 weeks gestation) with children of similar age born at term ( $\geq 37$ weeks gestation). Children born at 25-32 weeks gestation were also compared with children born at term.

Methods All births from the Avon Longitudinal Study of Parents and Children $(n=14049)$ who had lung spirometry at $8-9$ years of age $(n=6705)$ and/or $14-17$ years of age $(n=4508)$ were divided into four gestation groups.
\end{abstract}

Results At 8-9 years of age, all spirometry measures were lower in the 33-34-week gestation group than in controls born at term but were similar to the spirometry decrements observed in the 25-32-week gestation group. The 35-36-week gestation group and term group had similar values. In the late preterm group, at 14-17 years of age forced expiratory volume in $1 \mathrm{~s}$ $\left(\mathrm{FEV}_{1}\right)$ and forced vital capacity (FVC) were not significantly different from the term group but $\mathrm{FEV}_{1} / \mathrm{FVC}$ and forced expiratory flow at $25-75 \%$ FVC $\left(\mathrm{FEF}_{25-75 \%}\right)$ remained significantly lower than term controls. Children requiring mechanical ventilation in infancy at 25-32 and 33-34 weeks gestation had in general lower airway function ( $\mathrm{FEV}_{1}$ and $\mathrm{FEF}_{25-75}$ ) at both ages than those not ventilated in infancy.

Conclusions Children born at 33-34 weeks gestation have significantly lower lung function values at 8-9 years of age, similar to decrements observed in the 25-32-week group, although some improvements were noted by $14-17$ years of age.

\section{INTRODUCTION}

In most industrialised countries the rate of preterm birth has risen markedly in recent years and late preterm births form a substantial proportion of these. In the USA the rate has increased from 9.5\% in 1981 to $12.7 \%$ in 2005 , with $20 \%$ of the preterm births occurring at 32-33 weeks gestation and $60-70 \%$ at $34-36$ weeks gestation. ${ }^{1}$ Therefore, even a small increased risk of later respiratory morbidity in infants born beyond 32 weeks gestation will contribute substantially to the number of individuals affected by respiratory disease associated with preterm birth. A workshop convened by the National Institute of Child Health and Human Development recognised the importance of infants

\section{Key messages}

What is the key question?

- We sought to compare lung function at 8-9 and 14-17 years in children born late preterm (33-34 and 35-36 weeks gestation) with children of similar age born at term ( $\geq 37$ weeks gestation). We also compared children born at $25-32$ weeks gestation with children born at term.

\section{What is the bottom line?}

- Children born at 33-34 weeks gestation have significantly lower lung function values at 8-9 years of age, similar to decrements observed in the 25-32-week group, although most of these differences were reduced by 14-17 years of age.

\section{Why read on?}

- The findings from this longitudinal populationbased observational cohort study suggest that children born at 33-34 weeks gestation may be at risk of decreased lung function at 8-9 years of age. By 14-17 years of age there were improvements in $\mathrm{FEV}_{1}$.

born beyond 32 weeks gestation but identified the lack of outcome data for this population. ${ }^{2}$ It is, however, increasingly recognised that late preterm infants have increased respiratory morbidity in the neonatal period, especially neonatal respiratory distress syndrome, transient tachypnoea of the newborn and pneumonia. ${ }^{3}$ Few studies have reported later respiratory outcomes in children born late preterm, ${ }^{45}$ with most studies on lung function outcomes following preterm birth focusing on extremely preterm infants of 32 weeks gestation or less, especially as they are at risk of developing chronic lung disease of prematurity (CLD). ${ }^{6}$

Prematurity is associated with delivery of an infant at early stages of lung development with the focus traditionally having been on those born at 32 weeks gestation or less. ${ }^{7}$ As these infants are born at the late canalicular and early saccular stages of lung development, they often require intervention especially to support their respiratory system. However, those born 'late' preterm (ie, 33-34 weeks gestation) are also at a vulnerable stage of lung development (the late saccular stage), ${ }^{8}$ and it is unknown if normal lung growth and 
development continues normally in the extrauterine environment after preterm birth. Infants born at 35-36 weeks gestation are often termed 'near term' infants (eg, in the ECMO and Nitric Oxide clinical trials ${ }^{9-11}$ ) and are often assumed to behave like term infants, but it is unclear if being born at an early stage of alveolar development also results in adverse longer term respiratory outcomes.

In this study we sought to compare lung function at 8-9 and 14-17 years in a population-based cohort of children born late preterm at 33-34 weeks gestation and near term at 35-36 weeks gestation with children of similar age born at term ( $\geq 37$ weeks gestation). We also compared the results for these two gestation groups with children of similar age born extremely preterm at 25-32 weeks gestation. The longitudinal change in lung function between $8-9$ and $14-17$ years of age is also reported.

\section{METHODS}

\section{Avon Longitudinal Study of Parents and Children (ALSPAC)}

The study used data from the Avon Longitudinal Study of Parents and Children (ALSPAC) which has been described previously. ${ }^{12}$ Additional detail is provided in the online supplement.

\section{Gestation groups and perinatal data}

Gestational age was based on maternal reporting and medical assessments. ${ }^{13}$ All children who had spirometry results at either 8-9 or 14-17 years of age were divided into four groups based on gestational age: 25-32 weeks, 33-34 weeks, 35-36 weeks and $\geq 37-43$ weeks (term control). Perinatal data on respiratory management were extracted from hospital records. Additional detail is provided in the online supplement.

\section{Self-reported respiratory symptoms and tobacco smoke exposure}

As part of ALSPAC studies, questionnaires at 7.6 years of age established if children 'ever had asthma diagnosed by a doctor together with symptoms and/or treatment in the previous 12 months'. Questionnaires at 13.8 years of age established if the children 'ever had asthma diagnosed by a doctor'. Regular smoking at age 14 was defined as the usual smoking of at least one cigarette per day or at least six cigarettes per week.

\section{Lung spirometry}

Spirometry was performed at 8-9 and 14-17 years of age as previously reported. ${ }^{14}$ The variables forced expiratory volume in $1 \mathrm{~s}\left(\mathrm{FEV}_{1}\right)$, forced vital capacity (FVC) and forced expiratory flow at $25-75 \%$ of $\mathrm{FVC}\left(\mathrm{FEF}_{25-75}\right)$ were recorded and transformed to $\mathrm{SD}$ scores adjusted for age, sex and height according to the method of Chinn et al in the ALSPAC cohort independently at 8-9 and 14-17 years of age. ${ }^{15} \mathrm{FEV}_{1} / \mathrm{FVC}$ and $\mathrm{FEF}_{25-75} / \mathrm{FVC}_{\text {were }}$ calculated as markers of airway obstruction and dysanapsis. ${ }^{16}$

\section{Bronchial challenge}

At 8-9 years of age children, unselected for asthma or wheezing, had a bronchial challenge test with methacholine using the method of Yan et al, ${ }^{17}$ as previously described. ${ }^{14}$ Additional detail is given in the online supplement.

\section{Statistical analysis}

Gestations of $\geq 44$ weeks were considered implausible and thus excluded. The birth weight z-scores were calculated using the lms Growth program (Medical Research Council, UK) to take into account gestation, as the numbers in the earlier gestation groups were small and the birth weights of the ALSPAC cohort were similar to published reference values (data not shown). Weight at the time of lung function testing was converted into a z-score within the ALSPAC cohort as the ALSPAC data showed a trend towards earlier growth (data not shown). Spirometry values are summarised using the mean with 95\% CIs. For longitudinal changes in spirometry, only data from children who had spirometry at both time points were included in the analyses. To account for confounders the spirometry data, already adjusted for age, gender and height, were further adjusted using general linear modelling for smoking during pregnancy and social class status based on father's occupation, which are well-described confounders of lung function and preterm delivery. Missing values of each confounder were coded into a separate missing category. Adjusted scores were calculated and used in subsequent analyses. Longitudinal changes were assessed using paired t tests on the adjusted spirometry values. Differences between different gestational age groups and the term group and between ventilated and non-ventilated infants were tested using independent samples $t$ tests. The results for ventilated and non-ventilated infants are given unadjusted for social class and smoking during pregnancy but are adjusted for age, gender and height. Bronchial hyper-responsiveness was compared between gestation groups by one-way analysis of variance. $\chi^{2}$ Tests were used to compare asthma rates between gestation groups at 7.6 and 13.8 years of age. $p$ values $<0.05$ were considered statistically significant. All analyses were performed using SPSS V.16 (SPSS Inc).

\section{RESULTS}

From 14049 live births, spirometry data were available for 6705 $(47.7 \%)$ children at $8-9$ years of age and $4508(32.1 \%)$ at 14-17 years of age, with measurements at both ages available for $3799(27.0 \%)$ children (figure 1). Tables 1 and 2 show the characteristics of the children in each gestation group. A higher percentage of children in the 25-32-week gestation group were from lower social classes and had a higher prevalence of maternal smoking. A higher percentage of children who did not attend for spirometry were from a lower social class and had higher exposure to maternal smoking (table 3 ). $76 \%$ of the extremely preterm group and $17 \%$ of the late preterm group required mechanical ventilation but few $(\leq 1 \%)$ did so in the more mature groups (table 2).

Asthma in the previous year at 7.6 years of age was reported by more than $20 \%$ in the 25-32-week and 33-34-week gestation groups but by $<15 \%$ in the $35-36$-week gestation and term groups, although these differences were not statistically significant. The rates of asthma ever at 13.8 years of age were similar (23-30\%) in all groups. No differences were noted for smoking at 14 years of age between the gestational groups. Of the children who had any lung spirometry, 104 children reported regular smoking at 14 years of age (3 in the 35-36-week gestation group, 101 in the term group and none in those born at $<35$ weeks gestation).

Association of preterm birth with lung function in later childhood Spirometry data by gestation group at 8-9 and 14-17 years of age are shown in tables 4 and 5 , respectively. At 8-9 years of age, all spirometry measures were significantly lower in the 33-34week gestation group compared with the term group whereas values in the 35-36-week gestation group were similar to term infants. In the 25-32-week gestation group, all spirometry measures except FVC were significantly lower compared with the term group. The decrements of lung function were similar (table 4) between the 25-32-week and the 33-34-week 
Figure 1 Study profile: number of children excluded from group analysed. ALSPAC, Avon Longitudinal Study of Parent and Children.

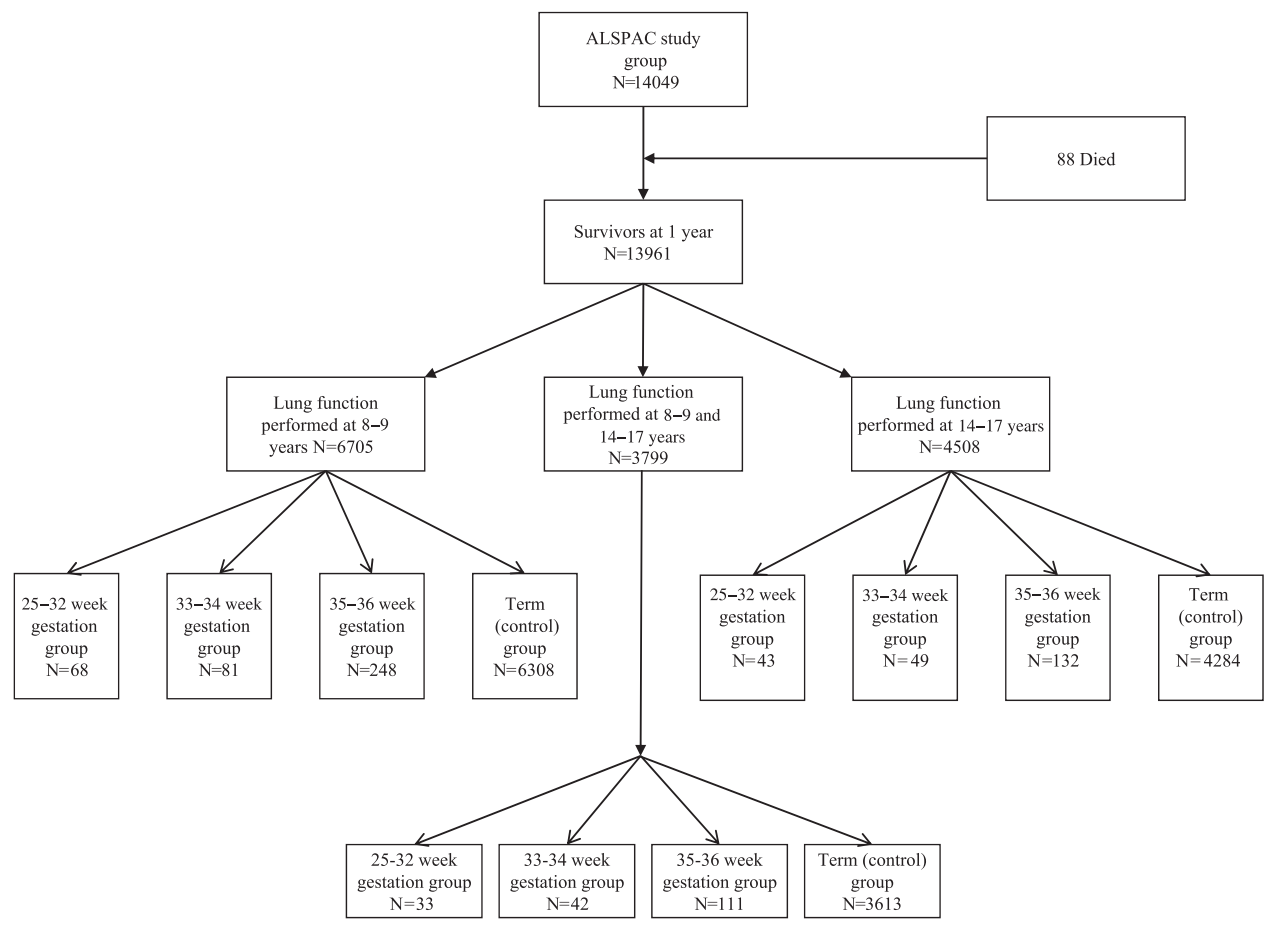

gestation groups. The approximate differences compared with term infants after adjustment for age, gender and height were $-143 \mathrm{ml}$ for $\mathrm{FEV}_{1},-98 \mathrm{ml}$ for FVC and $-253 \mathrm{ml} / \mathrm{s}$ for $\mathrm{FEF}_{25-75}$ in the 33-34-week gestation group and $-121 \mathrm{ml}$ for $\mathrm{FEV}_{1},-65 \mathrm{ml}$ for FVC and $-297 \mathrm{ml} / \mathrm{s}$ for $\mathrm{FEF}_{25-75}$ in the $25-32$ week gestation group.
At $14-17$ years of age, $\mathrm{FEF}_{25-75}, \mathrm{FEF}_{25-75} / \mathrm{FVC}$ and $\mathrm{FEV}_{1} / \mathrm{FVC}$ remained significantly lower in the late preterm group than in the term group but $\mathrm{FEV}_{1}$ and FVC were not significantly different. The approximate differences from those born at term after adjustment for age, gender and height were $-20 \mathrm{ml}$ for $\mathrm{FEV}_{1}, 156 \mathrm{ml}$ for FVC and $-382 \mathrm{ml} / \mathrm{s}$ for $\mathrm{FEF}_{25-75}$, in the 33-34-

Table 1 Characteristics of gestation groups

\begin{tabular}{|c|c|c|c|c|}
\hline & $\begin{array}{l}25-32 \text { weeks } \\
\text { gestation }\end{array}$ & $\begin{array}{l}33-34 \text { weeks } \\
\text { gestation }\end{array}$ & $\begin{array}{l}35-36 \text { weeks } \\
\text { gestation }\end{array}$ & Term \\
\hline Total liveborn & 185 & 169 & 522 & 13148 \\
\hline Survivors at 1 year & 160 & 165 & 519 & 13117 \\
\hline Had spirometry at $8-9$ years & $68(43 \%)$ & $81(49 \%)$ & $248(48 \%)$ & $6308(48 \%)$ \\
\hline Had spirometry at $14-17$ years & $43(27 \%)$ & $49(30 \%)$ & $132(25 \%)$ & $4284(33 \%)$ \\
\hline Had spirometry at $8-9$ years and $14-17$ years & $33(21 \%)$ & $42(25 \%)$ & $111(21 \%)$ & $3613(28 \%)$ \\
\hline Total number in group who had any spirometry & 78 & 88 & 269 & 6979 \\
\hline Male $(\%)$ & $48(62 \%)$ & $54(61 \%)$ & $144(54 \%)$ & $3446(49 \%)$ \\
\hline Maternal smoking (\%) & $21 / 74(28 \%)$ & $20 / 84(24 \%)$ & $49 / 264(19 \%)$ & $1282 / 6826(19 \%)$ \\
\hline Manual workers (\%) & $27 / 54(50 \%)$ & $32 / 77(42 \%)$ & $108 / 255(42 \%)$ & $2439 / 6431(38 \%)$ \\
\hline Exclusively breast fed for at least 3 months (\%) & $6 / 75(8 \%)$ & $12 / 84(14 \%)$ & $25 / 266(9 \%)$ & $819 / 6834(12 \%)$ \\
\hline \multicolumn{5}{|l|}{ At spirometry at $8-9$ years of age } \\
\hline Mean (SD) age (years) & $8.7(0.4)$ & $8.6(0.3)$ & $8.7(0.3)$ & $8.6(0.3)$ \\
\hline Mean (SD) height (cm) & $130.9(6.8)$ & $130.9(5.3)$ & $132.8(5.1)$ & $132.4(5.8)$ \\
\hline Mean (SD) height (z-score) & $-0.336(1.225)$ & $-0.252(0.945)$ & $0.036(0.883)$ & $0.011(1.002)$ \\
\hline Mean (SD) weight $(\mathrm{kg})$ & $28.1(6.4)$ & $28.3(4.2)$ & $30.4(6.0)$ & $30.3(5.8)$ \\
\hline Mean (SD) weight (z-score) & $-0.439(1.107)$ & $-0.363(0.738)$ & $-0.046(0.988)$ & $-0.033(0.990)$ \\
\hline \multicolumn{5}{|l|}{ At spirometry at $14-17$ years of age } \\
\hline Mean (SD) age (years) & $15.5(0.2)$ & $15.5(0.4)$ & $15.5(0.3)$ & $15.5(0.3)$ \\
\hline Mean (SD) height (cm) & $166.7(9.0)$ & $168.2(7.6)$ & $170.0(8.0)$ & $169.2(8.4)$ \\
\hline Mean (SD) height (z-score) & $-0.505(1.237)$ & $-0.202(0.972)$ & $0.028(0.933)$ & $0.007(0.998)$ \\
\hline Mean (SD) weight (kg) & $56.3(9.4)$ & $60.6(10.3)$ & $60.6(11.8)$ & $61.6(12.0)$ \\
\hline Mean weight (z-score, SD) & $-0.468(0.898)$ & $-0.090(0.840)$ & $-0.101(1.006)$ & $0.011(1.001)$ \\
\hline \multicolumn{5}{|l|}{ For children who had any spirometry } \\
\hline $\begin{array}{l}\text { Current asthma at } 7.6 \text { years of age based on reported } \\
\text { doctor-diagnosed asthma ever with symptoms and/or } \\
\text { treatment in previous } 12 \text { months }(\%)\end{array}$ & $11 / 52(21 \%)$ & $13 / 58(22 \%)$ & $22 / 182(12 \%)$ & $738 / 5221(14 \%)$ \\
\hline $\begin{array}{l}\text { Current asthma at } 13.8 \text { years of age based on } \\
\text { doctor-diagnosed asthma ever (\%) }\end{array}$ & $13 / 50(26 \%)$ & $17 / 57(30 \%)$ & $48 / 186(26 \%)$ & $1197 / 5227(23 \%)$ \\
\hline
\end{tabular}

Some of the variables reported had missing data but the denominators are given. 
Table 2 Neonatal characteristics of gestation groups

\begin{tabular}{|c|c|c|c|c|}
\hline & $\begin{array}{l}25-32 \text { weeks } \\
\text { gestation }\end{array}$ & $\begin{array}{l}33-34 \text { weeks } \\
\text { gestation }\end{array}$ & $\begin{array}{l}35-36 \text { weeks } \\
\text { gestation }\end{array}$ & Term \\
\hline Total liveborn & 185 & 169 & 522 & 13148 \\
\hline Survivors at 1 year & 160 & 165 & 519 & 13117 \\
\hline $\begin{array}{l}\text { Total number in group who had } \\
\text { any spirometry }\end{array}$ & 78 & 88 & 269 & 6979 \\
\hline $\begin{array}{l}\text { Mean (SD) birth weight of those } \\
\text { who had any spirometry }(\mathrm{g})\end{array}$ & $1437(439.5)$ & $2449(416.8)$ & $2634(424.7)$ & $3478(476.6)$ \\
\hline $\begin{array}{l}\text { Mean (SD) birth weight of those } \\
\text { who had any spirometry (z-score) }\end{array}$ & $0.051(1.297)$ & $0.396(1.267)$ & $0.180(1.066)$ & $\begin{array}{l}0.117 \\
(0.976)\end{array}$ \\
\hline $\begin{array}{l}\text { Mean (SD) gestation of those } \\
\text { who had any spirometry (weeks) }\end{array}$ & $29.7(2.0)$ & $33.6(0.5)$ & $35.7(0.5)$ & $39.7(1.3)$ \\
\hline Ventilated, $\mathrm{n} / \mathrm{N}(\%)^{*}$ & $59 / 78(76)$ & 15/88 (17) & $2 / 269(1)$ & $\begin{array}{l}12 / 6979 \\
(0.2)\end{array}$ \\
\hline $\begin{array}{l}\text { Mean (range) length of time of } \\
\text { ventilation (h) }\end{array}$ & $245(1-1416)$ & $77(9-168)$ & $15(8-22)$ & $107(1-576)$ \\
\hline \multicolumn{5}{|l|}{ Type of ventilation, $\mathrm{n} / \mathrm{N}(\%) \dagger^{*}$} \\
\hline CPAP & $43 / 78(55.1)$ & $6 / 88(6.8)$ & $2 / 269(0.7)$ & $3 / 6979(0.0)$ \\
\hline Ventilated via ETT & $41 / 78(52.6)$ & $7 / 88(8.0)$ & $0 / 269(0)$ & $\begin{array}{l}11 / 6979 \\
(0.2)\end{array}$ \\
\hline Other & $21 / 78(26.9)$ & $6 / 88(6.8)$ & $1 / 269(0.4)$ & $5 / 6979(0.1)$ \\
\hline Surfactant treatment, $\mathrm{n} / \mathrm{N}(\%)^{*}$ & $35 / 78$ (44.9) & $6 / 88(6.8)$ & $0 / 269(0)$ & $\begin{array}{l}1 / 6979 \\
(0.01)\end{array}$ \\
\hline $\begin{array}{l}\text { Received oxygen at any time, } \\
\mathrm{n} / \mathrm{N}(\%)^{*}\end{array}$ & $66 / 78(85)$ & $31 / 88(35)$ & $16 / 269(6)$ & $\begin{array}{l}45 / 6979 \\
(0.6)\end{array}$ \\
\hline \multicolumn{5}{|c|}{ Number $(\%)$ receiving oxygen treatment for: ${ }^{*}$} \\
\hline$<1$ day & $17 / 78(21.8)$ & 13/88 (14.8) & $8 / 269(3.0)$ & $\begin{array}{l}31 / 6986 \\
(0.4)\end{array}$ \\
\hline $2-4$ days & $11 / 78(14.1)$ & $8 / 88(9.1)$ & $7 / 269(2.6)$ & $9 / 6986(0.1)$ \\
\hline$\geq 5$ days & $38 / 78(48.7)$ & 10/88 (11.4) & $0 / 269(0)$ & $4 / 6986(0.1)$ \\
\hline
\end{tabular}

week gestation group and $-114 \mathrm{ml}$ for $\mathrm{FEV}_{1},-120 \mathrm{ml}$ for FVC and $-428 \mathrm{ml} / \mathrm{s}$ for $\mathrm{FEF}_{25-75}$ in the 25-32-week gestation group.

\section{Changes in spirometry between $8-9$ years and $14-17$ years of age}

Table 6 shows changes in spirometry for children with measurements at both time points. For the 33-34-week gestation group, significant increases were observed for $\mathrm{FEV}_{1}$. In contrast, no significant changes were noted between the time periods for the 25-32-week, 35-36-week and term groups.

Effect of ventilation in the newborn period on later lung function Table E1 (in the online supplement) shows spirometry for the extremely and late preterm children according to ventilation requirements in the newborn period. In general, children who

Table 3 Characteristics of attenders and non-attenders

\begin{tabular}{lll}
\hline & $\begin{array}{l}\text { Children } \\
\text { who had any } \\
\text { spirometry }\end{array}$ & $\begin{array}{l}\text { Children who had no } \\
\text { spirometry and were } \\
\text { alive at 1 year }\end{array}$ \\
\hline Number & 7414 & 6547 \\
Mean (SD) birth weight (g) & $3412(554)$ & $3369(565)$ \\
Mean (SD) gestation (weeks) & $39.4(1.9)$ & $39.4(1.9)$ \\
Male, N (\%) & $3692(49.8)$ & $3520(53.8)$ \\
Maternal smoking, N (\%) & $1372 / 7248(18.9)$ & $2033 / 5896(34.5)$ \\
Manual workers, N (\%) & $2606 / 6817(38.2)$ & $2407 / 4681(51.4)$ \\
Exclusively breast fed for at & $862 / 7259(11.9)$ & $470 / 5408(8.7)$ \\
least 3 months, N (\%) & & \\
\hline
\end{tabular}

were ventilated in infancy had lower airway function $\left(\mathrm{FEV}_{1}\right.$ and $\left.\mathrm{FEF}_{25-75}\right)$ at both ages compared with those not ventilated in infancy. More results are shown in the online supplement.

\section{Bronchial responsiveness}

No significant differences were found between the different gestation groups for the geometric mean provocative dose of methacholine causing a fall in $\mathrm{FEV}_{1}$ of $20 \%$ or more $\left(\mathrm{PD}_{20}\right)$ in either responders or the whole study population (table 7).

\section{DISCUSSION}

This study shows that most lung function variables measured by spirometry at $8-9$ years of age were significantly lower in infants born at 33-34 weeks gestation compared with term infants, with the effect sizes being very similar to those in the 25-32-week gestation group. By 14-17 years of age the differences in $\mathrm{FEV}_{1}$ and $\mathrm{FVC}$ attenuated but differences with term controls persisted for $\mathrm{FEF}_{25-75 \%}, \mathrm{FEV}_{1} / \mathrm{FVC}$ and $\mathrm{FEF}_{25-75 \%} / \mathrm{FVC}$ in the 33-34-week gestation group. In contrast, children born at 35-36 weeks had comparable lung function with children born at term at both follow-ups. While the numbers were small, the indications were that those in the 33-34-week gestation group who required mechanical ventilation fared worse than those who did not.

Late preterm infants of 33-34 weeks gestation are a growing population which is increasingly recognised to be at risk of morbidity in the neonatal period from respiratory diseases including respiratory distress syndrome ${ }^{18}$ and in infancy from 
Table 4 Mean and SD of z-score of lung function measures adjusted for age, gender and height at age 8-9 years, with Cls for the difference of means (premature - term), unadjusted and adjusted for maternal smoking in pregnancy and social status

\begin{tabular}{|c|c|c|c|c|c|c|c|}
\hline & \multicolumn{2}{|c|}{$\begin{array}{l}25-32 \text { weeks } \\
(n=65)\end{array}$} & \multicolumn{2}{|c|}{ Term $(n=6144)$} & \multirow{2}{*}{$\begin{array}{l}\text { Difference }(95 \% \mathrm{CI}) \\
\text { (unadjusted) }\end{array}$} & \multirow{2}{*}{$\begin{array}{l}\text { Difference }(95 \% \mathrm{CI}) \\
\text { (adjusted) }\end{array}$} & \multirow{2}{*}{$\begin{array}{l}\text { p Value } \\
\text { for adjusted } \\
\text { analysis }\end{array}$} \\
\hline & Mean & SD & Mean & SD & & & \\
\hline $\mathrm{FEV}_{1}$ & -0.461 & 0.876 & 0.011 & 1.000 & $-0.472(-0.716$ to -0.228$)$ & $-0.487(-0.791$ to -0.184$)$ & 0.002 \\
\hline FVC & -0.204 & 0.950 & 0.005 & 1.001 & $-0.209(-0.453$ to 0.035$)$ & $-0.151(-0.454$ to 0.152$)$ & 0.329 \\
\hline $\mathrm{FEF}_{25-75}$ & -0.573 & 0.928 & 0.013 & 1.001 & $-0.586(-0.829$ to -0.342$)$ & $-0.627(-0.930$ to -0.325$)$ & $<0.001$ \\
\hline $\mathrm{FEV}_{1} / \mathrm{FVC}$ & -0.362 & 1.183 & 0.009 & 0.997 & $-0.371(-0.617$ to -0.125$)$ & $-0.488(-0.793$ to -0.182$)$ & 0.002 \\
\hline \multirow[t]{3}{*}{$\mathrm{FEF}_{25-75} / \mathrm{FVC}$} & -0.457 & 0.963 & 0.010 & 1.001 & $-0.467(-0.713$ to -0.221$)$ & $-0.512(-0.818$ to -0.207$)$ & 0.001 \\
\hline & \multicolumn{2}{|c|}{$\begin{array}{l}33-34 \text { weeks } \\
(n=79)\end{array}$} & \multicolumn{2}{|c|}{ Term $(n=6144)$} & \multirow{2}{*}{$\begin{array}{l}\text { Difference and } 95 \% \mathrm{CI} \\
\text { (unadjusted) }\end{array}$} & \multirow{2}{*}{$\begin{array}{l}\text { Difference and } 95 \% \mathrm{CI} \\
\text { (adjusted) }\end{array}$} & \multirow{2}{*}{$\begin{array}{l}\text { p Value } \\
\text { for adjusted } \\
\text { analysis }\end{array}$} \\
\hline & Mean & SD & Mean & SD & & & \\
\hline $\mathrm{FEV}_{1}$ & -0.498 & 1.094 & 0.011 & 1.000 & $-0.509(-0.733$ to -0.285$)$ & $-0.485(-0.724$ to -0.246$)$ & $<0.001$ \\
\hline FVC & -0.313 & 1.036 & 0.005 & 1.001 & $-0.318(-0.540$ to -0.096$)$ & $-0.352(-0.589$ to -0.115$)$ & 0.004 \\
\hline $\mathrm{FEF}_{25-75}$ & -0.425 & 1.095 & 0.013 & 1.001 & $-0.438(-0.659$ to -0.217$)$ & $-0.434(-0.670$ to -0.197$)$ & $<0.001$ \\
\hline $\mathrm{FEV}_{1} / \mathrm{FVC}$ & -0.312 & 1.169 & 0.009 & 0.997 & $-0.320(-0.545$ to -0.096$)$ & $-0.239(-0.477$ to -0.001$)$ & 0.049 \\
\hline \multirow[t]{3}{*}{$\mathrm{FEF}_{25-75} / \mathrm{FVC}$} & -0.271 & 1.059 & 0.010 & 1.001 & $-0.281(-0.503$ to -0.060$)$ & $-0.267(-0.503$ to -0.031$)$ & 0.027 \\
\hline & \multicolumn{2}{|c|}{$\begin{array}{l}35-36 \text { weeks (n } \\
=238 \text { ) }\end{array}$} & \multicolumn{2}{|c|}{ Term $(n=6144)$} & \multirow{2}{*}{$\begin{array}{l}\text { Difference and } 95 \% \mathrm{CI} \\
\text { (unadjusted) }\end{array}$} & \multirow{2}{*}{$\begin{array}{l}\text { Difference and } 95 \% \mathrm{CI} \\
\text { (adjusted) }\end{array}$} & \multirow{2}{*}{$\begin{array}{l}\text { p Value } \\
\text { for adjusted } \\
\text { analysis }\end{array}$} \\
\hline & Mean & SD & Mean & SD & & & \\
\hline $\mathrm{FEV}_{1}$ & 0.008 & 0.908 & 0.011 & 1.000 & $-0.003(-0.133$ to 0.127$)$ & $-0.012(-0.147$ to 0.123$)$ & 0.867 \\
\hline FVC & 0.015 & 0.950 & 0.005 & 1.001 & $0.010(-0.120$ to 0.139$)$ & $0.009(-0.125$ to 0.143$)$ & 0.893 \\
\hline $\mathrm{FEF}_{25-75}$ & -0.010 & 0.879 & 0.013 & 1.001 & $-0.023(-0.152$ to 0.106$)$ & $-0.034(-0.168$ to 0.099$)$ & 0.616 \\
\hline $\mathrm{FEV}_{1} / \mathrm{FVC}$ & 0.004 & 0.906 & 0.009 & 0.997 & $-0.005(-0.135$ to 0.125$)$ & $-0.017(-0.151$ to 0.117$)$ & 0.805 \\
\hline $\mathrm{FEF}_{25-75} / \mathrm{FVC}$ & -0.022 & 0.925 & 0.010 & 1.001 & $-0.033(-0.162$ to 0.097$)$ & $-0.037(-0.171$ to 0.096$)$ & 0.582 \\
\hline
\end{tabular}

$\mathrm{FEF}_{25-75}$, forced expiratory volume at $25-75 \%$ of $\mathrm{FVC}$; FEV , forced expiratory volume in $1 \mathrm{~s}$; FVC, forced vital capacity.

respiratory viruses such as respiratory syncytial virus. ${ }^{19}$ A large study of over 150000 singleton births at 34-41 weeks gestation showed rates of severe respiratory disorders in neonates decreased with increasing gestational age (from $19.8 \%$ at 34 weeks to $0.28 \%$ at $39-41$ weeks). ${ }^{20}$ Using the raised volume rapid thoracic compression technique, Friedrich et al reported decreased airway flows despite normal FVC at 4 and 16 months of age in healthy late preterm infants. However, it is unclear if decreased lung

Table 5 Mean and SD of z-scores of lung function measures adjusted for age, gender and height at age 14-17 years, with Cls for the difference of means (premature - term), unadjusted and adjusted for maternal smoking in pregnancy and social status

\begin{tabular}{|c|c|c|c|c|c|c|c|}
\hline & \multicolumn{2}{|c|}{$\begin{array}{l}25-32 \text { weeks } \\
(n=42)\end{array}$} & \multicolumn{2}{|c|}{$\underline{\text { Term }(n=4105)}$} & \multirow{2}{*}{$\begin{array}{l}\text { Difference }(95 \% \mathrm{CI}) \\
\text { (unadjusted) }\end{array}$} & \multirow{2}{*}{$\begin{array}{l}\text { Difference }(95 \% \mathrm{CI}) \\
\text { (adjusted) }\end{array}$} & \multirow{2}{*}{$\begin{array}{l}\text { p Value } \\
\text { for adjusted } \\
\text { analysis }\end{array}$} \\
\hline & Mean & SD & Mean & SD & & & \\
\hline $\mathrm{FEV}_{1}$ & -0.186 & 0.850 & 0.001 & 1.004 & $-0.186(-0.494$ to 0.121$)$ & $-0.145(-0.534$ to 0.244$)$ & 0.464 \\
\hline FVC & -0.151 & 1.034 & -0.004 & 1.002 & $-0.148(-0.452$ to 0.156$)$ & $-0.041(-0.427$ to 0.346$)$ & 0.836 \\
\hline $\mathrm{FEF}_{25-75}$ & -0.438 & 0.899 & 0.011 & 1.001 & $-0.449(-0.753$ to -0.145$)$ & $-0.382(-0.768$ to 0.005$)$ & 0.053 \\
\hline $\mathrm{FEV}_{1} / \mathrm{FVC}$ & -0.195 & 1.117 & 0.010 & 0.995 & $-0.205(-0.517$ to 0.106$)$ & $-0.150(-0.535$ to 0.236$)$ & 0.446 \\
\hline \multirow[t]{3}{*}{$\mathrm{FEF}_{25-75} / \mathrm{FVC}$} & -0.260 & 1.006 & 0.013 & 1.000 & $-0.274(-0.581$ to 0.034$)$ & $-0.338(-0.723$ to 0.046$)$ & 0.084 \\
\hline & \multicolumn{2}{|c|}{$\begin{array}{l}33-34 \text { weeks } \\
(n=49)\end{array}$} & \multicolumn{2}{|c|}{ Term $(n=4105)$} & \multirow{2}{*}{$\begin{array}{l}\text { Difference and } 95 \% \mathrm{Cl} \\
\text { (unadjusted) }\end{array}$} & \multirow{2}{*}{$\begin{array}{l}\text { Difference and } 95 \% \mathrm{CI} \\
\text { (adjusted) }\end{array}$} & \multirow{2}{*}{$\begin{array}{l}\text { p Value } \\
\text { for adjusted } \\
\text { analysis }\end{array}$} \\
\hline & Mean & SD & Mean & SD & & & \\
\hline $\mathrm{FEV}_{1}$ & -0.022 & 1.135 & 0.001 & 1.004 & $-0.023(-0.304$ to 0.259$)$ & $-0.059(-0.348$ to 0.231$)$ & 0.691 \\
\hline FVC & 0.169 & 0.905 & -0.004 & 1.002 & $0.173(-0.109$ to 0.454$)$ & $0.127(-0.161$ to 0.415$)$ & 0.386 \\
\hline $\mathrm{FEF}_{25-75}$ & -0.279 & 1.143 & 0.011 & 1.001 & $-0.290(-0.572$ to -0.009$)$ & $-0.289(-0.577$ to -0.001$)$ & 0.049 \\
\hline $\mathrm{FEV}_{1} / \mathrm{FVC}$ & -0.401 & 1.104 & 0.010 & 0.995 & $-0.411(-0.693$ to -0.130$)$ & $-0.379(-0.666$ to -0.092$)$ & 0.010 \\
\hline \multirow[t]{3}{*}{$\mathrm{FEF}_{25-75} / \mathrm{FVC}$} & -0.415 & 0.984 & 0.013 & 1.000 & $-0.428(-0.709$ to -0.147$)$ & $-0.397(-0.683$ to -0.110$)$ & 0.007 \\
\hline & \multicolumn{2}{|c|}{$\begin{array}{l}35-36 \text { weeks } \\
(n=129)\end{array}$} & \multicolumn{2}{|c|}{ Term $(n=4105)$} & \multirow{2}{*}{$\begin{array}{l}\text { Difference and } 95 \% \mathrm{Cl} \\
\text { (unadjusted) }\end{array}$} & \multirow{2}{*}{$\begin{array}{l}\text { Difference and } 95 \% \mathrm{CI} \\
\text { (adjusted) }\end{array}$} & \multirow{2}{*}{$\begin{array}{l}\text { p Value } \\
\text { for adjusted } \\
\text { analysis }\end{array}$} \\
\hline & Mean & SD & Mean & SD & & & \\
\hline $\mathrm{FEV}_{1}$ & 0.057 & 0.859 & 0.001 & 1.004 & $0.057(-0.120$ to 0.234$)$ & $0.094(-0.089$ to 0.276$)$ & 0.315 \\
\hline FVC & 0.095 & 0.956 & -0.004 & 1.002 & $0.099(-0.077$ to 0.274$)$ & $0.119(-0.060$ to 0.299$)$ & 0.191 \\
\hline $\mathrm{FEF}_{25-75}$ & -0.077 & 0.877 & 0.011 & 1.001 & $-0.088(-0.263$ to 0.087$)$ & $-0.056(-0.235$ to 0.124$)$ & 0.543 \\
\hline $\mathrm{FEV}_{1} / \mathrm{FVC}$ & -0.079 & 1.047 & 0.010 & 0.995 & $-0.089(-0.267$ to 0.088$)$ & $-0.062(-0.243$ to 0.119$)$ & 0.502 \\
\hline $\mathrm{FEF}_{25-75} / \mathrm{FVC}$ & -0.137 & 0.957 & 0.013 & 1.000 & $-0.151(-0.326$ to 0.024$)$ & $-0.133(-0.311$ to 0.045$)$ & 0.143 \\
\hline
\end{tabular}

\footnotetext{
$\mathrm{FEF}_{25-75}$, forced expiratory volume at $25-75 \%$ of $\mathrm{FVC}$; $\mathrm{FEV}_{1}$, forced expiratory volume in $1 \mathrm{~s}$; FVC, forced vital capacity.
} 
Table 6 Mean and SD of z-scores of lung function measures adjusted for age, gender and height at age 8-9 and 14-17 years, with Cls for the difference of means (14-17 -8-9 years of age), unadjusted and adjusted for maternal smoking in pregnancy and social status

\begin{tabular}{|c|c|c|c|c|c|c|c|}
\hline & \multicolumn{2}{|c|}{$\begin{array}{l}25-32 \text { weeks: } \\
\text { age } 8-9(n=30)\end{array}$} & \multicolumn{2}{|c|}{$\begin{array}{l}25-32 \text { weeks: age } \\
14-17(n=30)\end{array}$} & \multirow{2}{*}{$\begin{array}{l}\text { Difference }(95 \% \mathrm{CI}) \\
\text { (unadjusted) }\end{array}$} & \multirow{2}{*}{$\begin{array}{l}\text { Difference }(95 \% \mathrm{CI}) \\
\text { (adjusted) }\end{array}$} & \multirow{2}{*}{$\begin{array}{l}\text { p Value } \\
\text { for adjusted } \\
\text { analysis }\end{array}$} \\
\hline & Mean & SD & Mean & SD & & & \\
\hline $\mathrm{FEV}_{1}$ & -0.441 & 0.946 & -0.318 & 0.932 & $0.123(-0.258$ to 0.504$)$ & $0.013(-0.471$ to 0.497$)$ & 0.958 \\
\hline FVC & -0.032 & 1.050 & -0.052 & 0.918 & $-0.021(-0.408$ to 0.367$)$ & $-0.275(-0.764$ to 0.214$)$ & 0.271 \\
\hline $\mathrm{FEF}_{25-75}$ & -0.717 & 0.944 & -0.572 & 0.909 & $0.145(-0.202$ to 0.491$)$ & $0.227(-0.214$ to 0.688$)$ & 0.313 \\
\hline $\mathrm{FEV}_{1} / \mathrm{FVC}$ & -0.605 & 1.294 & -0.438 & 1.132 & $0.167(-0.211$ to 0.546$)$ & $0.397(-0.082$ to 0.877$)$ & 0.104 \\
\hline \multirow{3}{*}{$\mathrm{FEF}_{25-75 /} \mathrm{FVC}$} & -0.665 & 0.941 & -0.509 & 0.949 & $0.156(-0.184$ to 0.496$)$ & $0.296(-0.134$ to 0.727$)$ & 0.177 \\
\hline & \multicolumn{2}{|c|}{$\begin{array}{l}33-34 \text { weeks: } \\
\text { age } 8-9(n=42)\end{array}$} & \multicolumn{2}{|c|}{$\begin{array}{l}33-34 \text { weeks: } \\
\text { age } 14-17(n=42)\end{array}$} & \multirow{2}{*}{$\begin{array}{l}\text { Difference }(95 \% \mathrm{CI}) \\
\text { (unadjusted) }\end{array}$} & \multirow{2}{*}{$\begin{array}{l}\text { Difference }(95 \% \mathrm{CI}) \\
\text { (adjusted) }\end{array}$} & \multirow{2}{*}{$\begin{array}{l}\text { p Value } \\
\text { for adjusted } \\
\text { analysis }\end{array}$} \\
\hline & Mean & SD & Mean & SD & & & \\
\hline $\mathrm{FEV}_{1}$ & -0.483 & 1.039 & -0.079 & 1.191 & $0.404(0.082$ to 0.726$)$ & $0.347(0.015$ to 0.680$)$ & 0.041 \\
\hline FVC & -0.090 & 0.938 & 0.130 & 0.960 & $0.220(-0.108$ to 0.547$)$ & $0.226(-0.562$ to 0.111$)$ & 0.188 \\
\hline $\mathrm{FEF}_{25-75}$ & -0.622 & 1.127 & -0.336 & 1.173 & $0.287(-0.006$ to 0.580$)$ & $0.241(-0.062$ to 0.544$)$ & 0.119 \\
\hline $\mathrm{FEV}_{1} / \mathrm{FVC}$ & -0.621 & 1.272 & -0.432 & 1.156 & $0.190(-0.130$ to 0.510$)$ & $0.143(-0.187$ to 0.473$)$ & 0.395 \\
\hline \multirow[t]{3}{*}{$\mathrm{FEF}_{25-75} / \mathrm{FVC}$} & -0.566 & 1.052 & -0.445 & 1.017 & $0.121(-0.166$ to 0.408$)$ & $0.112(-0.183$ to 0.408$)$ & 0.456 \\
\hline & \multicolumn{2}{|c|}{$\begin{array}{l}35-36 \text { weeks: } \\
\text { age } 8-9(n=107)\end{array}$} & \multicolumn{2}{|c|}{$\begin{array}{l}\text { 35-36 weeks: } \\
\text { age } 14-17(n=107)\end{array}$} & \multirow{2}{*}{$\begin{array}{l}\text { Difference }(95 \% \mathrm{CI}) \\
\text { (unadjusted }\end{array}$} & \multirow{2}{*}{$\begin{array}{l}\text { Difference }(95 \% \mathrm{CI}) \\
\text { (adjusted) }\end{array}$} & \multirow{2}{*}{$\begin{array}{l}\text { p Value } \\
\text { for adjusted } \\
\text { analysis }\end{array}$} \\
\hline & Mean & SD & Mean & SD & & & \\
\hline $\mathrm{FEV}_{1}$ & 0.148 & 0.863 & 0.021 & 0.860 & $-0.127(-0.332$ to 0.079$)$ & $-0.130(-0.343$ to 0.084$)$ & 0.234 \\
\hline FVC & 0.115 & 0.941 & 0.045 & 0.955 & $-0.070(-0.275$ to 0.135$)$ & $-0.097(-0.308$ to 0.115$)$ & 0.370 \\
\hline $\mathrm{FEF}_{25-75}$ & 0.086 & 0.900 & -0.076 & 0.888 & $-0.161(-0.345$ to 0.022$)$ & $-0.132(-0.322$ to 0.059$)$ & 0.175 \\
\hline $\mathrm{FEV}_{1} / \mathrm{FVC}$ & 0.006 & 0.911 & -0.048 & 1.076 & $-0.054(-0.258$ to 0.150$)$ & $-0.007(-0.218$ to 0.205$)$ & 0.951 \\
\hline \multirow[t]{3}{*}{$\mathrm{FEF}_{25-75} / \mathrm{FVC}$} & 0.027 & 0.970 & -0.104 & 0.992 & $-0.131(-0.311$ to 0.049$)$ & $-0.095(-0.281$ to 0.091$)$ & 0.318 \\
\hline & \multicolumn{2}{|c|}{$\begin{array}{l}\text { Term weeks: } \\
\text { age } 8-9(n=3431)\end{array}$} & \multicolumn{2}{|c|}{$\begin{array}{l}\text { Term weeks: age } \\
14-17(n=3431) \\
\end{array}$} & \multirow{2}{*}{$\begin{array}{l}\text { Difference }(95 \% \mathrm{CI}) \\
\text { (unadjusted) }\end{array}$} & \multirow{2}{*}{$\begin{array}{l}\text { Difference }(95 \% \mathrm{CI}) \\
\text { (adjusted) }\end{array}$} & \multirow{2}{*}{$\begin{array}{l}\text { p Value } \\
\text { for adjusted } \\
\text { analysis }\end{array}$} \\
\hline & Mean & SD & Mean & SD & & & \\
\hline $\mathrm{FEV}_{1}$ & -0.004 & 1.006 & 0.010 & 1.002 & $0.014(-0.021$ to 0.051$)$ & $-0.013(-0.060$ to 0.034$)$ & 0.582 \\
\hline FVC & -0.019 & 1.003 & 0.005 & 1.001 & $0.025(-0.012$ to 0.061$)$ & $0.007(-0.054$ to 0.040$)$ & 0.774 \\
\hline $\mathrm{FEF}_{25-75}$ & 0.014 & 0.997 & 0.010 & 1.001 & $-0.005(-0.037$ to 0.028$)$ & $-0.016(-0.058$ to 0.027$)$ & 0.468 \\
\hline $\mathrm{FEV}_{1} / \mathrm{FVC}$ & 0.016 & 1.003 & 0.003 & 0.982 & $-0.013(0.049$ to 0.023$)$ & $-0.006(-0.053$ to 0.041$)$ & 0.801 \\
\hline $\mathrm{FEF}_{25-75} / \mathrm{FVC}$ & 0.023 & 1.005 & 0.005 & 0.989 & $-0.017(-0.049$ to -0.014$)$ & $-0.011(-0.052$ to -0.031$)$ & 0.616 \\
\hline
\end{tabular}

$\mathrm{FEF}_{25-75}$, forced expiratory volume at $25-75 \%$ of $\mathrm{FVC} ; \mathrm{FEV}_{1}$, forced expiratory volume in $1 \mathrm{~s}$; FVC, forced vital capacity.

function persists into childhood and beyond. Our data show that the preterm group of 33-34 weeks gestation have lower spirometry measurements than those born at term at 8-9 years of age; however, improvement was observed for $\mathrm{FEV}_{1}$ by 14-17 years of age but not for other measurements. The extremely preterm group had similar effect sizes but, in contrast, the 35-36-week gestation group had similar lung function to the term control group at both ages. Infants at 33-34 weeks gestation are born at the stage of saccular development ${ }^{8}$ and early delivery may alter their subsequent alveolar development, as has been suggested for extremely preterm infants. ${ }^{21}$ Interventions such as mechanical ventilation and oxygen therapy are well known to promote pulmonary inflammation in infancy leading to abnormal growth and development. ${ }^{6}$ Although the numbers are small, especially as only $17 \%$ of the 33-34-week gestation group required mechanical ventilation in infancy, the data appear to support the notion that intervention is associated with worse spirometry at 8-9 years, which did not appear to improve to the same degree as for the non-ventilated group between the two ages (table E1 in online supplement). The interpretation is further complicated by the fact that mechanical ventilation was likely to be instituted in infants with underlying lung disease which may already identify them as candidates for future lung abnormalities. Other possible explanations for the poorer lung function in the

Table 7 Bronchial responsiveness at $8-9$ years of age

\begin{tabular}{|c|c|c|c|c|}
\hline & $25-32$ weeks & 33-34 weeks & $35-36$ weeks & Term \\
\hline Number who had lung function at $8-9$ years & 68 & 81 & 248 & 6308 \\
\hline $\begin{array}{l}\text { Number (\%) who were excluded or did not } \\
\text { complete the challenge for the reasons listed below* }\end{array}$ & $35(51.5 \%)$ & $34(42.0 \%)$ & $90(36.3 \%)$ & $2185(34.6 \%)$ \\
\hline Number $(\%)$ who responded to methacholine challenge & $9(27.3 \%)$ & $9(19.1 \%)$ & $22(13.9 \%)$ & $646(15.7 \%)$ \\
\hline Geometric mean $\mathrm{PD}_{20}$ in responders $(\mu \mathrm{mol})$ & $1.20(0.43,3.35)$ & $2.25(1.08,4.70)$ & $2.27(1.50,3.42)$ & $1.71(1.57,1.87)$ \\
\hline $\begin{array}{l}\text { Geometric mean } \mathrm{PD}_{20} \text { for the whole population who } \\
\text { underwent the challenge }(\mu \mathrm{mol})\end{array}$ & $6.46(4.15,10.04)$ & $8.86(7.08,11.09)$ & $9.62(8.65,10.69)$ & $8.96(8.73,9.19)$ \\
\hline
\end{tabular}

\footnotetext{
${ }^{*}$ Children did not start or complete the challenge for a number of reasons: the child refused whole/part of session, parent refused, parents did not attend, staff illness/difficulties, need doctor, child ill or taking medications, time restraint, equipment error/failure, staff error (general), child started coughing, child problems/difficulties with task, couldn't get reproducible FEV, excluded due to $\mathrm{FEV}_{1}<70 \%$ predicted.
} 
33-34-week gestation group are an adverse prenatal environment associated with preterm delivery (eg, chorioamnionitis may affect later lung function $)^{22-25}$ or dysregulated lung growth associated with premature cessation of late gestational development. The loss of late intrauterine lung maturation in the 33-34-week gestational group suggests that lung growth may be dysregulated after birth resulting in physiological differences compared with those completing term gestation.

We noted poorer lung function in childhood in the late preterm children which was similar to the extremely preterm group, but did not note significant differences in rates of asthma between the gestation groups. It would be interesting to investigate if the decreased $\mathrm{FEV}_{1}$ can be reversed by bronchodilators as was recently shown for children who were born extremely preterm. ${ }^{26}$ Furthermore, if there is plasticity of the airways, bronchodilators may be effective in this group of children, but whether they improve longer term airway function needs further investigation. Few studies have reported longitudinal lung function in preterm infants with most focusing on severe long-term respiratory consequences-that is, those who develop CLD. In a small number of children with CLD, often also called bronchopulmonary dysplasia, Filippone et al reported that airflow limitation tracked between 2 and 8.8 years of age did not show improvements between the two time points. ${ }^{27}$ In contrast, Doyle and colleagues reported significant improvements in predicted values of lung function between 8 and 14 years of age in children with a birth weight $<1501 \mathrm{~g}^{28}$ When we compared the preterm children who had spirometry at both time periods, our data support potential improvements in lung function in children born at 33-34 weeks gestation from 7-8 years of age to 14-17 years, especially for the larger airways. For the 25-32-week gestation group, relative improvements were noted in the $z$-scores for lung spirometry but these were not statistically significant. While tracking appears to be an attractive concept, our longitudinal data question the concept of tracking as lung function improved between $7-8$ and 14-17 years of age. More recent imaging modalities such as the use of hyperpolarised helium may assist in investigating lung growth and development beyond infancy ${ }^{29}$ to clarify if, indeed, continued growth and development occurs beyond infancy.

While we acknowledge that the data were not specifically collected to address the current hypothesis, the strength of this study is that it uses data from a large unselected populationbased cohort with comprehensive longitudinal data with reasonable numbers of preterm-born children and a large number in the term control group. A further strength is that spirometry was measured using the same methods at the two time points and is an objective outcome. As with all cohort studies, a major weakness is the loss to follow-up and the resulting potential attrition bias. Fewer children who had mothers who smoked during pregnancy and a from lower social class attended for lung spirometry compared with the attenders. Since lower social class is associated with more preterm births, more maternal smoking and decreased attendance for spirometry, it is possible that a higher rate of attendance in these children would have increased the observed differences. In addition, ALSPAC did not measure the lung function of severely disabled children and, as these represent the severe end of morbidity associated with preterm delivery, the differences may have been attenuated by their exclusion. We included children from ethnic minorities in our analysis as there were very few of them (in the whole ALSPAC cohort only $5 \%$ of the children who reported their ethnic background reported being non-white), and the ALSPAC cohort is broadly representative of the population of the UK. ${ }^{12}$
In summary, our data show that, at 8-9years of age, measures of airway function are reduced in children born at 33-34 weeks gestation compared with children born at term, and are of similar magnitude to those in the extremely preterm group who received a much higher proportion of respiratory intervention during the neonatal period. However, by 14-17 years of age, there was no significant difference in $\mathrm{FEV}_{1}$ and FVC in the late preterm group compared with children born at term, although $\mathrm{FEV}_{1} / \mathrm{FVC}$ and $\mathrm{FEF}_{25-75 \%}$ remained significantly lower than term controls. This raises the question about what occurs from a lung development point of view between $33-34$ and $35-36$ weeks of gestation. Now that there is a strong suspicion of respiratory physiological abnormalities in late preterm-born children, it will be interesting to study in more detail whether they are at greater risk of respiratory infections in infancy, have increased respiratory symptoms or indeed have limitation of exercise with or without exercise-induced bronchoconstriction.

Acknowledgements We are grateful to all the families who took part in this study, the midwives for their help in recruiting them and the whole ALSPAC team which includes interviewers, computer and laboratory technicians, clerical workers, research scientists, volunteers, managers, receptionists and nurses. We thank Dr David Herrick for his help in identifying relevant perinatal data.

Funding The Avon Longitudinal Study of Parents and Children (ALSPAC) receives core funding from the UK Medical Research Council, the Wellcome Trust and the University of Bristol. The lung function measures were supported by a grant from the UK Medical Research Council (G0401540). SJK was partially supported by Nutricia Research Foundation.

\section{Competing interests None.}

Ethics approval This study was conducted with the approval of the ALSPAC Law and Ethics Committee and the local research ethics committees.

Contributors All authors led by SK were involved in study design including hypothesis generation and execution. AJH is co-director of ALSPAC and was involved in collection of the data. FD and WJW were primarily responsible for statistical analyses. SJK and SK wrote the initial drafts of the paper which was contributed to by all authors. SK is the guarantor.

Provenance and peer review Not commissioned; externally peer reviewed.

Data Sharing Statement Data generated by the ALSPAC study are held as a national resource. Data are anonymised at entry and held separately from administrative data; therefore, identification of individual subjects' data is concealed from researchers. Access to data items is provided on application to the ALSPAC Executive Committee. The full ALSPAC collaboration policy, including details of data sharing arrangements, is published online at: http://www.bris.ac.uk/alspac/sci-com/collab-policy/.

\section{REFERENCES}

1. Goldenberg RL, Culhane JF, lams JD, et al. Preterm birth 1. Epidemiology and causes of preterm birth. Lancet 2008;371:75-84.

2. Raju TN, Higgins RD, Stark AR, et al. Optimizing care and outcome for late-preterm (near-term) infants: a summary of the workshop sponsored by the National Institute of Child Health and Human Development. Pediatrics 2006; 118:1207-14.

3. The Consortium on Safe Labour. Respiratory morbidity in late preterm births JAMA 2010;304:419-25.

4. Friedrich L, Pitrez PM, Stein RT, et al. Growth rate of lung function in healthy preterm infants. Am J Respir Crit Care Med 2007;176:1269-73.

5. Todisco T, de Benedictis FM, lannacci L, et al. Mild prematurity and respiratory functions. Eur J Pediatr 1993;152:55-8.

6. Chakraborty M, McGreal EP, Kotecha S. Acute lung injury in preterm newborn infants: mechanisms and management. Paediatric Respir Rev 2010;11:162-70.

7. Colin AA, McEvoy C, Castile RG. Respiratory morbidity and lung function in preterm infants of 32 to 36 weeks' gestational age. Pediatrics 2010;126:1115-28.

8. Kotecha S. Lung growth: implications for the newborn infants. Arch Dis Child Fetal Neonatal Ed 2000;82:F69-74.

9. Bennett CC, Johnson A, Field DJ, et al. UK collaborative randomised trial of neonatal extracorporeal membrane oxygenation: follow-up to age 4 years. Lancet 2001;357:1094-6.

10. Cornfield DN, Maynard RC, deRegnier RO, et al. Randomized, controlled trial of lowdose inhaled nitric oxide in the treatment of term and near-term infants with respiratory failure and pulmonary hypertension. Pediatrics 1999;104:1089-94. 
11. NINOS Study Group. Inhaled nitric oxide in term and near-term infants: neurodevelopmental follow-up of the Neonatal Inhaled Nitric Oxide study group (NINOS). $J$ Pediatr 2000;136:611-17.

12. Golding J, Pembrey M, Jones R, et al. ALSPAC - the Avon Longitudinal Study of Parents and Children I. Study methodology. Pediatr Perinat Epidemiol 2001;15:74-87.

13. Lawlor DA, Cooper AR, Bain C, et al. Association of birth size and duration of breast feeding with cardiorespiratory fitness in childhood: findings from the Avon Longitudinal Study of Parents and Children (ALSPAC). Eur J Epidemiol 2008;23:411-22.

14. Kotecha SJ, Watkins WJ, Heron J, et al. Spirometric lung function in school-age children. Effect of intrauterine growth retardation and catch-up growth. Am J Respir Crit Care Med 2010;181:969-74.

15. Chinn S, Rona RJ. Height and age adjustment for cross sectional studies of lung function in children aged 6-11 years. Thorax 1992;47:707-14.

16. Munkata M, Ohe M, Homma Y, et al. Pulmonary dysanapsis, methacholine airway responsiveness and sensitization to airborne antigen. Respirology 1996;2:113-18

17. Yan K, Salcome C, Woolcock AJ. Rapid method for measurement of bronchial responsiveness. Thorax 1983:38:760-5.

18. Melamed N, Klinger G, Tenenbaum-Gavish K, et al. Short-term neonatal outcome in low-risk, spontaneous, singleton, late preterm deliveries. Obstet Gynecol 2009:14:253-60.

19. Boyce TG, Mellen BG, Mitchel EF Jr, et al. Rates of hospitalization for respiratory syncytial virus infection among children in Medicaid. J Pediat 2000;137:860-70
20. Gouyon JB, Vintejoux A, Sagot P, et al. Neonatal outcome associated with singleton birth at 34-41 weeks of gestation. Int J Epidemiol 2010;39:769-76.

21. Jobe AJ. The new BPD: an arrest of lung development. Pediatr Res 1999:46:641-3.

22. Maxwell NC, Davies PL, Kotecha S. Antenatal infection and inflammation: what's new? Curr Opin Infect Dis 2006:19:253-8.

23. Thomas W, Speer CP. Chorioamnionitis: important risk factor or innocent bystander for neonatal outcome? Neonatology 2011;99:177-87.

24. Watterberg KL, Demers LM, Scott SM, et al. Chorioamnionitis and early lung inflammation in infants in whom bronchopulmonary dysplasia develops. Pediatrics 1996;97:210-15.

25. Ogunyemi D, Murillo $\mathrm{M}$, Jackson $\mathrm{U}$, et al. The relationship between placental histopathology findings and perinatal outcome in preterm infants. J Matern Fetal Neonatal Med 2003;13:102-9.

26. Fawke J, Lum S, Kirkby J, et al. Lung function and respiratory symptoms at 11 years in children born extremely preterm. Am J Respir Crit Care Med 2010:182:237-45.

27. Filippone $\mathbf{M}$, Sartor $\mathbf{M}$, Zacchello $\mathbf{F}$, et al. Flow limitation in infants with bronchopulmonary dysplasia and respiratory function at school age. Lancet 2003:361:753-4.

28. Doyle LW, Chavasse R, Ford GW, et al. Changes in lung function between 8 and 14 years in children with birth weight of less than $1,501 \mathrm{~g}$. Pediatr Pulmonol 1999:27:185-90.

29. Sukstanskii AL, Conradi MS, Yablonskiy DA. ${ }^{3} \mathrm{He}$ lung morphometry technique: accuracy analysis and pulse sequence optimization. J Magn Reson 2010:207:234-41.

\section{Journal club}

\section{Differentiation of malignant pleural mesothelioma from other pleural diseases}

In this study, pleural effusion samples from 101 patients with suspected or newly diagnosed malignant pleural mesothelioma (MPM) or metastatic adenocarcinoma (ADCA) were collected between 1998 and 2010. Of the 101 patients, 65 were diagnosed with MPM, 25 with ADCA and 15 with benign pleural effusion. Cancer cells isolated from pleural effusion samples were subjected to genome-wide gene expression analysis, done with the help of microarrays and real-time PCR.

The study found 74 genes coding for markers that were overexpressed in MPM and 9 genes that were overexpressed in ADCA. The highest expression in MPM cells was the gene COL3A1, coding for type III collagen. Immunohistochemistry demonstrated 100\% staining of MPM biopsy samples with antibodies specific for COL3A1 and no staining in ADCA.

Soluble markers such as CCL2 and galectin-3 were identified as useful markers for diagnosing MPM. CCL2 concentration was significantly higher in patients with MPM than in patients with ADCA or benign pleural effusion whereas galectin-3 was significantly lower in MPM compared with ADCA. CCL2 and COL3A1 can be used as positive markers, whereas galectin-3 can be used as a negative marker. Statistical analysis using receiver operating characteristic curve and sensitivity suggested that both these markers performed better than existing markers in differentiating MPM from other pleural diseases.

Although type III collagen, CCL2 and galectin-3 markers have been shown to be valuable diagnostic aids, a large multicentre study is required to validate these results and investigate other potential markers.

Gueugnon F, Leclercq S, Blanquart C, et al. Identification of novel markers for the diagnosis of malignant pleural mesothelioma. Am J Pathol 2011;178:1033-42.

\section{R Bhardwaj}

Correspondence to Dr R Bhardwaj, Foundation Year 1, St James University Hospital, Leeds, UK; rahulbhardwaj@doctors.org.uk

Published Online First 17 May 2011

Thorax 2012;67:61. doi:10.1136/thoraxjnl-2011-200355 